\title{
Towards Re-Sacralization of Nordic Law?
}

\section{Christoffersen, Lisbet}

\section{Published in:}

Formatting Religion

\section{Publication date:}

2019

Citation for published version (APA):

Christoffersen, L. (2019). Towards Re-Sacralization of Nordic Law? In M. T. Mjaaland (Ed.), Formatting Religion: Across Politics, Education, Media, and Law (pp. 175-204). Routledge. Ethics, Human Rights and Global Political Thought

\section{General rights}

Copyright and moral rights for the publications made accessible in the public portal are retained by the authors and/or other copyright owners and it is a condition of accessing publications that users recognise and abide by the legal requirements associated with these rights.

- Users may download and print one copy of any publication from the public portal for the purpose of private study or research.

- You may not further distribute the material or use it for any profit-making activity or commercial gain.

- You may freely distribute the URL identifying the publication in the public portal.

Take down policy

If you believe that this document breaches copyright please contact rucforsk@kb.dk providing details, and we will remove access to the work immediately and investigate your claim. 


\title{
11
}

\section{TOWARDS RE-SACRALIZATION OF NORDIC LAW?}

\author{
Lisbet Christoffersen
}

\section{Introduction: the question to be analyzed and its historical background ${ }^{1}$}

On Jantary 30,2017 , the general assembly of the Church of Norway, by 83 votes out of 112 , decided to introduce a new liturgy for same-sexmarriages. The new liturgy, wlich is in operation from February 1, 2017, is an appendix to the already existing rituals for marringe, dating from 2003.

The decision is historic in many ways. In this chapter I do not focus on the question of same-sex-marriage or religious blessing of these. It is thus not my intention to get involved in the discussions concerning theological legitimacy of the decision, that is, the discussion which is hidden behind the numbers of votes. Instend, my focus is on legality, the question of competences: What made the General Assembly of the Church of Norway conpetent to decide on this liturgy? That is: What made the decision legal?

Such questions about legality might seem odd to readers outside the west Nordic countries. ${ }^{2}$ For most renders in Europe and in the United States it secms obvious that the legal basis for a decision concerning rituals is made internally in the Church. For them, a church is defined, among others, through its right to self-governance, at least when it comes to liturgy and rituals. Thus, for external readers, the question of legality and that of theological legitimacy are intimately linked to each other.

In the west Nordic countries, however, the Reformation also led to royal legislative competences over not only ecclesiastical law, or jus circa sacra, but also internal affairs in the Lutheran churcles, such as rituals, etc., jtts in sacra. With the absolutist legishation (Norwegian Law of 1687) the concept of 'church' even disappeared, and the law only spoke of how the king and the state organized the religious dimensions of civil service. In Norway, the royal competence was from 1814 regarded as a prerogative for the king, even though the gradual introduction of parliamentary goversment after the political crisis in 1884 to some extent developed into a situation of 
TOWARDS RE-SACRALIZATION OF NORDIC LAW?

for the church as church? Alternatively, is the competence derived from the statutory law, which (dis)-established the Church of Norway with certain competences? In that case, is the Church of Norway still, in all its dimensions including rituals, etc., a "by law established' Church, or is it only the organization of the Church (the 'ordering'), which is by law established or even less?

Such questions are, of course, mostly of theoretical interest. ${ }^{9}$ No one imagines that the Norwegian Parliament in a foreseeable time would pass a law, aimed at withdrawing the competence regarding rituals from the Church Assembly and returning the competence to the king or to the Parliament. One can, however, imagine a fiture where the General Assembly of the Church of Norway wanted to exclude baptized Norwegians from being members of the Church on grounds established in internal ruling. Or one could imagine a future where the newly established rituals were made redundant (here the number of votes in the first decision appears relevant). Would it then be possible for the Norwegian Parliament by law to re-establish the situation? Or is it no longer possible to withdraw the competence given to the Church of Norway, beciuse the Church is now covered by constitutional or international legal norms on freedom of religion and belief that give the Church a legislative power of its own, independent of the law of the land?

If the latter is the case, then gateways are open for a re-sacralization of (parts of) Norwegian law. One could of course argue that internal regulations made by the Church of Norway are not 'law', but 'governance'. However, that does not clange anything. Naming internal regulations of the Church 'governance regulations' does not change their effect. The crucial question is: Would it be possible for a future Church Assembly to change or strengthen the norms in order to establish a more rigorous church distipline over its members, or to withdraw membership rights, without any possibility for the Parliament, the government or the Norwegian courts to take any legal steps? If that is the case, then a re-sacralization of a legal order has taken place. Secular Norwegian administrative law on ecclesiastical affairs has changed identity into canon law of the Church of Norway. Another question is whether this is a new situation; I come back to that in the discussion in the end of this chapter.

\section{Theoretical basis: Norwegian constitutional theory}

In order to establish a theoretical basis for answering the question regarding re-sacralization of parts of Norwegian law, it appears relevant to identify basic norms in Norweginn constitutional law. Which legislative, executive 
TOWARDS RE-SACRALIZATION OF NORDIC LAW?

According to Norwegian constitutional law theory, Parliament thus has the legislative competences, unless constitutional human rights establish a material framework, against which legislation is not possible. Delegation of the Parliament's legislative comperences is possible by law only and within the possible purpose formulated in the constitution. A delegation of legislative power cas be withdrawn again or even supplemented by parliamentary law at any time.

Freedom of religion and belief does, however, establish a significant limitation of state powers [trossamfunnsvern]. Smith develops the discussion further by referring to the concept of relative constitutional protection, introduced into the Norwegian constitutional debate by other scholars (Snith 2015a, p. $357 \mathrm{ff}$ ). In a conflict between legislative interpretation of the constitution and the interpretation of a citizen in a case against the state from a private individual or private organization regarding the interpretation of a piece of legislation against the constitutional basis, this concept implies that the parliamentary interpretation of the constitution should be given higher weight. The argument behind this position is that the courts should not overturn democracy in its legislative powers. Parliamentary democracy, contrary to the non-elected judges, gives legislation legitimacy.

Smith's position is clear: He does not accept a better position for Parliament in the interpretation of relations between legislation and the constitution, especially not if the conflict regards material protection of individuals or groups, as is the case in relation to FROB. The consequence would be that any protection of constitutional rights would vanish (Smith 2015a, p. 360). Apart from that, the argument is also that the constitution itself does not establish such a power for the Parliament. If the Parliament wanted to change material rights and legislate against them, then Parliament must first change the constitution. So goes the argument. As long as the constitution establishes materiai protection for, for example, FROB rights, these material rights must also be respected by the legislative powers.

It is interesting against this background to see how Smith analyses FROB. And his position is as clear as that of Andenxs/Fiflet: FROB is a wall against legislation into the religious communities. Smith names this wall ordre public, meaning that some (but not all!) criminal law violations are prohibited for everyone, no matter which religious conviction might be behind the breaking of the law. Among these crimes, Smith mentions murder, manslaughter, bodily harm and offence against the person. The point is that for Smith, ordre public is not an argument for any legislative intervention into internal affairs in religious communities or any intervention into practices of freedom of religion or belief for the individual. 
now or later, then it would have to build upon an argument, which wis clearly based on constitutional orders that again could be accepted in international courts.

In the following parts of this chapter, I will discuss how the legislative powers have undersrood their competences regarding rituals for the Cluurch of Norway (and other similar matters) in relation to the process of changing the constitution, the legislation established alongside and the legislative process establishing Cluurch of Norway as an independent legal entity. The question is whether there are any elements left of a theory of 'by law delegated' competences for the Church of Norway, or whether the theoretical standpoint, leading to a sti generis competence for the Church of Norway, based on freedom of religion and belief, has fully taken over. In what follows, I will first discuss the constitutional change of $\mathbf{2 0 1 3}$ alongside the parallel legislation and afterwards the legislation of 2016 (in force January 1, 2017) concerning establishing the Church of Norway as an independent, legal body.

\section{Constitutional change of 2013 and parallel legislation}

The religion clauses of the Norwegian Constitution were changed on May 21, 2012 , by a decision in the Parliament. ${ }^{13}$ The proposal (constitutional proposal no 10, 2007-2008 $)^{14}$ was based on an agreement of April 10, 2008, between all the political parties represented in Parliament. This political agreement is included in the constitutional proposal and is thus relevant for the interpretation of the new text. The political agreenent was however only binding for the parliamentary period 2009-13, which means that a changed political landscape within the norms in the amended constiturion could change the ideas belind it. Most of the political agreement was thus not constitutionalized and does not bind the interpretative analysis of the constitution.

The political agreement consisted of seven itents: ${ }^{15}$

- The Church of Norway shall have an independent basis in the constiturion.

- The Church must still be regulated through one law on the Church, however, without being an independent legal subject.

- Priests, bishops, etc., should still be regarded and salaried as civil servants of the state.

- The regional and central administration of the Church should still be part of the state administration.

- General public law on insight in decisions are still binding for the Church.

- The municjpal involvement in Church administration and decision making should be kept. 
TOWARDS RE-SACRALIZATION OF NORDIC LAIV?

material linit for lcgislative competences within FROB implies, that parliament cannot go too far into internal affairs of the Church of Norway and that 'ordering' concerns the organization of the church, not the internal affairs. ${ }^{20}$

This time, the department clearly stated that a wall of separation between legislative competences of the state and normative regulatory competences of the Church exists on basis of freedom of religion and belief norms.

Even this position did obviously not clarify the ground sufficiently. There was still a legal possibility that the constitution opened not only for legislation concerning the structure and competences of the Church but also for legislation concerning the content of internal affairs, such as rituals.

Therefore, the department in 2007-08 in the first proposals regarding legislation alongside with the changed constitution proposed a "justin-case' piece of legislation. ${ }^{21}$ According to the proposal, the Law on the Church of Norway should elearly in \$ 24 state that "the Church Assembly as the leading representative body in the Cluurch of Norway decides on the liturgy, rituals, etc., to be used in the Church".22

In the Parliament, the question of how to interpret the proposed legislation was also discussed. The parliamentary committee thus added that

the intention of the constitutional change was to clarify the free position of the Church of Norway as a religious community. This implies that the religious practice in the church will no longer be the task of the state. The state must however support the church as a religious community as well as support other religious communitics equaliy. The parliamentary committee approved of the understanding that these changes represent a new fundament for the development of the Church of Norway as an independent religious community. The committee equally underlined how central it is to ensure that the changes contribute to the purpose for the Church of Norway to remain an open, inclusive and democratic people's church. ${ }^{23}$

The changed constitution made it impossible to proceed with the royal decrees concerning the internal affairs (rituals, etc.) of the Church of Norway. The 'ordering' of the Church was still the conspetence of the Parliament. Thus, the Church of Norway, through its Church Assembly, received its competences regarding the rituals from the state by law. And mosr of the arguments presented from both the department (the government) and the Parliament were arguments underlining that this was a just-in-case piece of 
law on marriage and made same-sex-couples equal with couples of opposite sex in the law (in force from lst January 2009). In the Nordic countries, pastors in the churches have traditionally had powers to perform marriages with civil validity. The Norwegian law of 2009 underlined, that this could only be done in Church of Norway (and any other religious community) on basis of a ritual that - for Church of Norway - was approved by the King (according to the constitutional system before 2012).

This development already in May 2009 forced the Church Assensbly to reconsider the question of a rittal concerning same-sex-marriages. A committee to consider the matter was organized, but did not deliver any results, until 11 February 2013, that is: well after the changed constitution as well as relevant legislation, confirming the competences of Church of Norway in ritual matters, was in force. - however, again the report of February 2013 did not lead to any decision in the competent bodies of the Church of Norway, neither at the general assembly in 2014 or 2015.

By decision at the general assembly, a principled acceptance of a ritual for same-sex-marriages won majority, but the ritual should still be formulated, discussed and approved of. This happened in the course of summer 2016, after which the church assembly consequently could accept and acknowledge the ritual at its meeting 25-31 January 2017. The new liturgy is in force from 1st February 2017. ${ }^{25}$

The question of whether people, living in same-sex-couples could be ordained for services in the Church of Norway, was indirectly solved by the non-decision in 2007, where the former rejecting decisions were dissolved. The question regarding rituals for same-sex-marriage was, however, pending and still so after the change of the constitution. One could reflect on, whether this delay came by accident - or whether it had to do with what still could be interpreted as unclear conpetences in core internal matters, such as decision-competences regarding rituals etc.

The point of departure in constitutional theory was, as mentioned, 2 to that churches, and even the Church of Norway before the changed constitution, have FROB rights when it comes to competences for the state to decide on, especially rituals. If the state should have competence in such matters, constitutional theory would thus require that the competence be clearly backed by the constitution. The wording of the 2012 constitution (regulation of the ordering of the Church) did, however, leave sufficiently clear interpretative room for a position arguing that the state still had the competence. Thus, the need for the 'just-in-case' legislation placing the competence with the Church Assembly.

Some would, however, argue that this was still not enough. If the formulation in the church law, $\$ 24$, on competences for General Assembly 
When the new Parliament and the next government took seats, those who had hoped to see the problems solved for the next long period had to realize the weakness they already knew regarding this part of the 2008 political agreement. The Solberg government, which took seats in October 2013 and remained in office after the public elections in 2017, stated in its governmental program (2013), that it would establish

"a clear distinction berween church and state", and "lead a politic which makes it possible for the church to uphold the status as an open church for everyone". - "The government will formulate one law for all faith and life-stance communirics"; and the government will "ensure that internal self-decision-powers is a reality in all faith- and life-stance communities". ${ }^{28}$

The Solberg government was renewed and widened after the public elections in 2017. The governmental programme (2018) states that the government will "complete the distinction between state and church". ${ }^{29}$

With the 2012 reform as 'the constitutional reform', this new reform was less intruding and therefore called 'adninistrative' [ forvaltningsreformen ]. There is, however, no doubt that with these latter changes, the real changes in the status of the Church of Norway were to be implemented. From previously having been part of the Norwegian state to becoming nearly almost, although not fully, a private entity in line with other religious communities (that would require further constitutional changes), but at least an entity barely part of the state anymore.

With this political programme, the Department of Cultural Affairs (with the section on Church Affairs) developed a paper sent out for public remarks called 'The State and the Clsurch of Norway - A Clear Distinction'. ${ }^{30}$ Based on the comments on this paper, a revised paper was formulared by the Department of Cultural Affairs in March 2015 to be discussed at the General Assembly in the Church in the spring of 2015. ${ }^{31}$ Based on the reactions from the church assembly, a final proposal was sent to Parliament, ${ }^{32}$ and discussed in the committee on church, education and research affairs in its recommendation. ${ }^{33}$ The law on the Church of Norway as an independent legal subject has been in force since January 2017. At this same time an administrative reform took place: All previous civil servants, among them all priests, bishops, etc., are servants of the Church with the General Assembly as the ultimate employer.

The iden from the department was originally, comparable to the forms of regulation in Desmark and Iceland, that the Church of Norway should 


\section{TOWARDS RE-SACRALIZATION OF NORDIC LAW?}

individual freedom of religion and belief also must include a collective dimension, and that such religious communities must have freedom to perform their religious beliefs according to their rituals, symbols and traditions of common values and norms. The religious community, including the Church of Norway, on basis of the individual members' freedom of religion and belief must have a right on independent basis to decide on the frames for the ritual life and development of faith within the religious community. ${ }^{41}$

The church assembly did however succeed in changing the Church of Norway into a hierarchical organization. There were still political forces in Norway who wanted to keep a more traditional church, especially with respect to local independence. Parts of both political forces and Norway's broader population are hesitating to move to a too hierarchical church whereas others want one common church under the regulation of the church assembly. Here the Swedish and Finuish models are present as 'shadow-models', mentioned even by some congregation councils as something not fully received in this proposal. ${ }^{42}$

The department found it too early to implement models that would lead to further central governance of the Church. In its proposal to the Parliament, the department thus underlines that the local congregations are still legal subjects. The Cluurch is, as it is underlined in the legislative proposal to the Parliament, no hierarchical entity. The local congregations are independent legal subjects, and the church assembly can only regulate local matters, if they have a clear competence in law to do so. ${ }^{43}$

The sustained independence for the local congregation councils seens to have been a central point in the reform politically. This point is thus also underlined in the recommendations from the parliamentary committee. ${ }^{44}$ The question is burning: The partiamentary members from the social-democratic party underline in their recommendations that they do not necessarily support a further development where the local congregations might be hierarchical elements into one, unified church organization. ${ }^{45}$

Also the question abour a guarantec in the future to be able to have access to local priestly services seems to have played a central part. The new cherch law therefore states that the Church of Norway must still provide priestly service in all congregations (which here seems to be part of the concept of 'popular' or 'peoples' church), ${ }^{46}$ and the independence of the vicars and those who function as bishops are upheld by law. On the other 
TOWARDS RE-SACRALIZATION OF NORDIC LAW?

nearly nobody in the preparatory works have used the references to Danish religion politics or constitutional understanding, which does not stand out in a Scandinavian context as modern.

The wording folkekirke could, however, still be constitutionally relevant, even though a Danish parallel does not seen to be the most attractive. For both Smith and myself, the most striking thing is the coupling of folkekirke with an idea of openness and inclusiveness, both theologically, geographically and in practical terms (that is, openness for people's wish to use the church in their otdinary life). Smith rightly points to the attempts from the legislative authorities to ensure this openness and inclusiveness through a strong, internal democracy, but, as he also rightly states, a church with strengthened identity as religious community (faith community) invites its members to strengthen those dimensions of the identity that are not necessarily comfortable for every'one (Smith 2015b, p. 66)..$^{53}$

But this is precisely the argument for, why I think - contrary to what Smith suggests - that one must interpret the Norwegian constitutional use of the term folkckirke as legally relevant. And with the same general argument concerning constitutions that Smith alrendy uses as the general argument on relations between the constitution and legislation: ${ }^{54}$ If the Norwegian Parliament does not want to have its legislation bound by the wording in the constitution (here the wording folkckirke), then the Parliament must change the constitution first.

The point is that one must interpret the wording folkckirke in the constitution as a constitutional limitation against how far legislators and the keadership in the Church of Norway can change that specific Church from having been a Church whose internal structure was decided by all Norwegians through parliamentary democracy into a Church based on religious premises only. The question is whether a requirement regarding 'democratic' organization of the Church internally is enough to meet this constitutional requirement.

It is hard for Smith to imagine that the wording folkckirke could appear as a central parameter in a future court case concerning employment or other legally relevant decisions from the church bodies, not because he necessarily sees the concept as irrelevant, but because he thinks it is too unclear and does not see when it could become relevant.

I do not have problems in foreseeing exactly that case. Collective freedom of religion and belief and the rights acquired through that concept are said to rely on the freedom of belief of individual church members, and that dinension is, as already mentioned, underlined in the preparatory works in the legislation on the Church of Norway. One could, however, easily anticipate that conflicts arise in the future between Church members 


\section{TOWARDS RE-SACRALIZATION OF NORDIC LAW?}

Church of Norway by law. But it does not ensure sui generis rights for the Church if the Church uses these rights to restrict the rights for ordinary members. One could therefore argue thar the law on the Church of Norway ought to ensure rights for the Church members in such possible conflict situations, as well as ensuring access to bodies to get such rights clarified.

\section{By law established and sui generis}

The questions discussed in this chapter are whether the Church of Norway still is to be regarded as a church established by law, whose legal powers are based on delegation by law of state powers. The other possibility is that this church established by law at least in some elements, namely regarding powers to decide on rituals, relies sui generis on legal comperences derived from its members' freedom of religion and belief. The question is legally relevant in order to identify to which extent the Church of Norway also as a folkekirke is legally limited in its decisions or whether it - precisely as folkckivk - can decide through its own bodies what it takes to be a folkekirke in the 21 st-century religiously pluralistic Norway. The Parliament could of course re-organize the church order, based on the constitutional Article 16. It is also my understanding that the wording of Article 16 - both folkckirke and Evangelical-Lutheran includes some limitations to the possible change of the normative function of the Church of Norway by its own internal bodies. The Parliament must thus have some competence to be 'co-interpreter' of these two central concepes in a possible confliet with church bodics. On the other hand, as long as the Church of Norway is by law established with legal persona!ity, this implies that the Church could sue the state/the legislative powers in such a situation and argue that the state, contrary to FROB rights of the Church, had legislated against the Church's collective freedom of religion and belief.

There is no doubt that the legislative powers in close concertation with the church assembly of the Church of Norway has tried to come as far as possible to a new, legally independent body with sti generis rights to not only decide on rituals and other matters closely linked to jus in sacra. The route followed is also driven as far as possible regarding internal rights to decide on internal organization, jus circa sncra, even though the constitution undoubtedly confirms the Parliament with that right.

The constitution, on the other hand, is clear: The Church of Norway is an established church. The Parliament has the competence to establish it as evangelical-Lutheran and as folkckirke. This competence is not limited with constitutional references to collective freedom of religion and belief. 
TOWARDS RE-SACRALIZATION OF NORDIC LAW?

least half of the members of the Norwegian government had to be members of the state church so that these members could take part in decision making regarding internal affairs of the church. The argument goes ${ }^{59}$ that this made the king's governance of the chureh an internal affair - the king was (and maybe still is?) simply seen as the first annong equals or the first in the priesthood of all believers, implying that the king had religious legitimacy to take these decisions.

This argument is a perfect example of how we use the past in the legitimation of the present. ${ }^{60}$ That the king's competence once was based on a theological idea of the priesthood of all believers does not necessarily imply state powers presently are bound to the same line of argumentation.

It is tempting in this area to rely on an equality argument: The state cannot legislate further into the rituals of the Church of Norway than into other religious communities (which is the other side of the coin, ealled collective freedom of religion and belief, based on individual freedom of religion and belief). This is also the most often used argument in the preparatory works. I do, however, think that, even though it is very vague and unprecise, there still is some sort of protection of the members of the Church of Norway against decisions that are clearly in conflict with equity, when compared to the previous situation.

I also think this is the background for why the Church of Norway General Assembly did not decide on a ritual for same-sex marriage until after the 2017 legislation giving the Church legal personality was in force. On the one hand, the Church wanted to underline that the legitimacy in these matters generally are with decisions taken in church bodies. On the other hand, the church bodies wanted to acknowledge that they as a folkekirke building on traditions from the state church were (morally? politically?) obliged to take the entire group of members into account when deciding on church rituals.

The Church of Norway decided on a new ritual allowing for the marriage of same-sex couples and thereby including broad groups of society into the Church, just after the Church had acquired legal personality, in order to show that theological legitinacy, subsequent sui generis legality and by-law-established legality could be the same in the Cluurch of Norway' after 2017.

\section{Re-sacralization?}

There is a general tendency in international law on religions to peel off conflicts in and with religious communities from (stcular) law. Court 
TOWARDS RE-SACRALIZATION OF NORDIC LAW?

\section{Notes}

I I am thankful to Professor Eivind Smith, Faculty of Law, University of Oslo, to professor (mso) of practical theology, ph.d. Ulla Schmidt, Aarhus University, to professor of sociology of law, ph,d. Betrina Lemann Kristiansen and to docent cm., dr. theol, Anna Maric Aagaard, Aarhus, for extremely relevant comments to previous drafts of this article. All interpretations and possible mistakes of course remain on my shoulders.

2 The West Nordic Countrics are Dennark, Norway and Iceland that sliarc some of the legal consequences of the reformation of $1536 / 7$ onwards, if Christoffersen, Andersen and Modéer (cds.) (2010).

3 For a good overview over the development, however, underlining what he saw as the problematic dimensions of state involvement in church affairs, see Aarflot (2016). See also further articles, published together with Schmidt (2014).

4 The process towards church independence was much longer, but the events during WWII are highlighted in several contributions, see e.g. Morland (2018). For an overview, see also Sclımidt (2006).

5 Delegation from Royal Prerogative was the undisputed legal basis for these powers before the 21st-century change of constitution, see among others St. Meld. nr 17 (2007-2008) on the State and the Church, p. 24.

6 Sec c.g. St.Mcld. 17 (2007-2008), part 3.5.3.

7 https://kirken.no/nb-NO/om-kirken/aktuclt/2017-et-kirkehistoriskmerkear/

8 Ulla Schmidt $(2014$, p. 106) poses partly the same question by asking, whether the legislative powers on basis of the revised constitution of 2012 can only organize the external organization of the Church of Norway, or whether there is also a constitutional basis for the legislative powers to decide on internal matters.

9 Andreas Aarflot in his recent article raises the same type of questions by underlining, that "(der) savnes en tydeligere markering av den normgivningskompetanse som dette innebarer". [a clarification of the legislative competences, based on the legal subjectivity of the Church of Norway, is necessary] (Aarflot 2017, p. 211).

10 The 10. vol is as mentioned from 2006. The book is thus published a couple of years before the proposal, that lead to the reformulated constitution.

11 Which in itself is remarkable. In a recent public report on the legal status of the Danish national church [Betankning 1544/2014 Folkekirkens styre] this author took the same position, but was overthrown by the majority, including representatives of the Ministry of Justice and the Chairperson, Hans Gammeltoft-Hansen, former Ombudsman, former professor, dr.jur, and co-founder of the Association of Ecelesiastical law. See the mentioned public teport, chaprer 9.4.3., p 235.

12 "Derson man skulle onske a gjore unntak fra dette utgangspunkt gjennom lov, er det vanskelig a se noe annet enn at det vil matte kreves sarskilt hjenmel i grumnloven selv. . . . Men on det i forhold til Norges konvensjonsbestemte forpliktelser om religionsfriher vil vare tilstrekketig a hjemle lowbestemmelser av en slik karakter i den nasjonale grunnloven, er $\mathrm{i}$ beste fall et ápent sporsmal" 
TOWARDS RE-SACRALIZATION OF NORDIC LAW?

20 "antar departementet at forslaget til ny \$16 og prinsippet on tros- og livssynsfrilher vil innebare en tilstrekkelig skranke not for inngripende lovgivning om indrekirkelige forhold. Ordlyden i forslaget til ny $\$ 16$ i Grunnloven vil markere Den norske kirke som folkekirke og kirkens sarrlige stilling "som saadan" overfor staten. - Den tydeliggjar ogsá at Stortinget fortsatt kan og skal gi sarskilt lovgivning on Den norske kirke, og den uttrykker at lovgiveren fortsati kan gał lenger i l regulere Den norske kirke enn andre tros- og livssynssamfunn. Den typen lovgivning som sxrlig nevnes, er lovgivning om Den norske kirkes 'Ordning'. Dette omfatter bestemmelser om kirkens ytre organisering". (201 1, Kirkeforliket - konsekvenser av eventuclle endringer i Grunnlovens bestemmelser on statskirkeordningen i stortingsperioden 2009-2013. Horingsnotat 1. februar 2011, s. 18-19)

21 Prop. 7l L (2011-2012) Proposisjon til Stortinget (forslag til Lovvedtak) Endringer i kirkeloven m.m. s. 34: " I og for sig kunne en tenke sig at Kirkemoter, ogst uten eksplisitt lowhiemmel, ville ha myndighet til â fastsette liturgier og det tlihorende regelverket. Departementet ga likevel i høringsnotatet utrrykk for at de beste grunnene taler for at rydeliggjore i en ny lovbestemmelse at Kirkemotet har myndighet til \& vedta liturgier mv. til bruk i Den norske kirke. Departementet lagger til grunn at en ny lovbestemmelse on gudstjenstlig nuyndigher i princippet ikke trenger a bety at det er Stortinget som utstyrer Kirkemoret med denne myndiglieten. Lowbestemmelsen sikter mot tydeliggjore og bekrefte at Kirkemotet besitter denne myndigheten i kraft av sin rolle som trossamfunnet Den norske kirkes overste representative organ. Den eksplisitt rettslige virkningen av den foreslatte bestemmelsen er at den begrenser regjeringens ansvar og myndighet pà dette omrddet. När lovgivuingen bekrafter at det ligger til Kurkemotet a fastsette kirkens gudstjenstlige boker, avgrenser den regjeringens instruktionsmyndighet vedrorende dette. Dermed avgrenses også regjeringens ansvar for saksomraidet".

22 "Som overste representative organ i Den norske kirke fastsetter Kirkemotet alle gudstjenstlige boker i Kirken".

23 Innst. 202 L (2011-2012) Innstilling til Stortinget fra kirke-, utdanningsog forskningskomiteen, s. 3: "Komiteen viser til at gruntlovsendringene som folger av kirkeforliket har som intensjon a klargjøre Den norske kjrkes frie stilling som trossamfunn. Dette innebarer at den religiose virksomheten i Kirken jkke lenger vil vare statens oppgnve. Det er imidlertid statens oppgave a understotte Kirken som trossamfunn, og a understotte andre tros- og livssynssamfumn pa lik linje. Komi te e n slutter seg til forståclsen av at endringene representerer et nytt grunnlag for uevikling av Den norske kirke som selvstendig trossamfunn. K omi $t$ e e $n$ vil samtidig understreke viktigleten av a etablere sikkerhet for at endringene bidrar til a bevare Detn norske kitkes mal on à vare en apen, inkluderende og demokratisk folkekirke",

24 I do not go further into this - for a detailed analysis, sce the papers in Askeland and Schmidt (2016).

25 https://kirken.no/nb-NO/om-kirken/samfunnsansvar/lomotilisaken$1992 \cdot 2015 /$

26 See Eivind Smith (2015a, p. $390 \mathrm{ff})$.

27 Smith (2015a, a.st.). 
medlemmenes individuelle trosfrihet må trossamfunnet - ogsí Den norske kirke - pa sclvstendig grunn]ag kunne fastsette bl.a. rammene for trosfeilesskapets tituelle liv og trosopplaring". Kulturdepartementer Forslag til endringer i kirkeloven for behandling i Kirkemotet, 3. mars 2015, s 17. My transtation. The formulation is repeated in the proposal to the parliament, pkt. 2.1 .5$, s. 9.

42 Kulturdepartementet, mars 2015, s. 44. Aarflot (2017) is a discussion of this idea of local independence within Church of Norway.

43 Prop. 55 L (2015-2016) pkt.

44 Innst. $256 \mathrm{~L}$ (2015-2016) Innstilling til stortinget fra Kirke-, utdanningso gforskningskomiteen, s. 1.

45 Komieteens medlemmer fra Arbeiderpartiet og Senterpartiet, Innst. $256 \mathrm{~L}$, s. 4 , 2. spalte.

46 Innst 256 L- 2015-2016, s. 2, 1. sp.

47 If. the political platform for the current government, presented in footnote 29.

48 Den norske Kirke, en evangelisk-Juthersk Kirke, forbliver Norges Folkekirke og understottes som saadan af Staten. Narmere Bestemmelser on dens Ordning fastsxttes ved Lov. htips://lovdata.no/dokument/HIST/lov/ 1814-05-17-20120521 is translated into: The Church of Norway, an Evangelical-Lutheran church, will renain the Established Cluurct of Norway and will as such be supported by the State. Detailed provistons as to its system will be laid down by law. www.stortinget.no/en/In-English/ About-tlac-Storting/The-Constitution/

49 Sec for a discussion of the (many) different possible translations of the concept into Englisl, among others Lisbet Christoffersen, Svend Andersen \& Kjell A. Modéer (eds): Lan ơ Religion in the 21st Century-Nordic Perspectipes, DJOF Pbl, 2010, p. $145 \mathrm{ff}$. This author has also in the Danish context suggested that folkekirke should imply people's church or popular church, and that the 'ordering' of the church structure should not imply a competence to organize the internal matters.

50 See c.g. Gammoltoft-Hansen (2006).

51 Tonnessen (2006)

52 Moxness (2006)

53 "Den innebygde spenningen i dette synet som ligger i muligheten - eller faren for at kirken kan komme til h opptre som et trossanfunn i den forstand at den rendyrke en egenast som ikke passer til alle, bliver sjelden eller aldri tatt opp". Smith (2015b), s. 66. See also p. 68: Spenningen mellon apenhet og manken om en kirke som et fellesskap rundt laxesetninger som medlemmene selv oppfatter som sentralc, er i sig selv tilstrekkelig til a begrunne at det resultat som sả mange $i$ den politiske prosessen har onsket seg, ikke uten videre er girt. [the possible conflict berween openness and the iden of the church as a community around traditions that the members themselves regard as central, is in itself an argument for realizing the the result so many in the political process has wanted does not automatically appear].

54 Sec Smitl (2015b, p. $360 \mathrm{ff}$ ) on the constitutional limitation regarding legislation into material human rights.

55 This is a possible conflict, which Smith has not discussed in his works.

56 In a Danjsh case from the 1970 s a church minister required that the parents appeared for church services 12 times a year as a condition for baptizing 
the Lawa 1901-2017], in Niels Henrik Gregersen and Carsten Bach Nielsen (eds.): Reformationten [The Reformation], vol. 3, pp. 195-228, Odense: Syddansk Universitetsforlag.

Christoffersen, Lisber, Svend Andersen and Kjell A. Modéer (eds.) (2010): Law or Religion in the 2Ist Century: Nordic Perspectives, Copenhagen: DJOF Pbl.

Ganmeltoft-Hansen, Hans (2006): Kommentarer. $\$ 4,6,66-69$ [Commentarics on the Danish Constitutuion, art's 4, 6, 66-69 (Regulations Concerning Church and Religion)] i Henrik Zahle (red): Danmarks Riges Grundlov med kommentarer, Kobenhavn: DJOF forlag, 2. Udg.

Morland, Egil (2018, forthcoming): "New Relations between State and Church in Norway", accepted for publication in Europenn Jourmal of Theology.

Moxnes, Halvor (2006): “đApen, inkluderende folkekirke': Hvilke rettigheter har folk flest i folkekirken?" [Open, Inclusive Pcople's Church: Which Rights Do Ordinary Pcople Have in the Church?], in Njâl Hostmalingen, Tore Lindloolm and Ingvild Plesner (eds.): Stat, Kirke og Mcuneskerettigheter [State, Church and Human Rights], Oslo; abstmkt forlag, pp. $118-127$.

Schmidt, Ulla (2006): "Endring og tilhorighet blant kirkemedlemmer og borgere: - Hovedlinjer I debatten rundt Gjonnesutvalgets utredning" [Change and Church Belonging among Members of the Church and the Citizens], in Ulla Schmidt (cd.): Endring of tilhprighet - Stasshirksppensmilet i perspektiv, [Change and Belonging: State-Cluurch-Discussion in Perspective], Trondheim: Akatemisk Forlag.

Sclumidt, Ulla (2014): "Stat og Religion $\mathrm{j}$ Norge $i$ dag" [State and Religion in Norway loday], in Øystein Ekroll, Soren Hjorth, Einar Vegge (eds.): Vor Kristue og Humanistiske Arv-betraktningtr wed 200-îrsjubileat for Grannloven [Our Christian and Humanist Heritage: Reflections around 200-Years Jubilee for the Norwegian Constitution], Trondlicim: Nidaros Donkirkes Restaureringsarbeider, pp. 92-115.

Smith, Eivind (2015a): Konstitusjonelt Demokrati. Statsforfatmingstetten $i$ principiclt og komparntivt lys. [Constitutional Democracy: Constitutional Law, Enligtened Principally and Comparatively], 3rd ed., Oslo: Fagbok forlaget.

Smith, Eivind (2015b): "4. . f forblir Norges folkekirke': Om Grunnlovens ordvalg og dets juridiske konsekvenser" [Remain the Peoples Church of Norway: On Constitutional Wording and It's Legal Consequences], i Stephanie Dietrich, Hallgeir Elstad, Vidar L. Haanes and Beate Fagerli (cds.): Folkckirke nii. Oslo: Verbum, pp, 60-71.

Smith, Eivind (2006): "Stntskirke?" [Stnte-Church?], in Njäl Hostmalingen, Tore Lindholm, Ingvild Plesner (eds.): Stat, Kirke og Menneskerttiglieter [State, Church \& Human Rights], Oslo: Abstrakt, pp. 36-60.

Tonnessen, Aud. V. (2006): "Medborgerskap og kirkeordning" [Cirizenship and Church Structure], in Njäl Hostmalingen, Tore Lindholm and Ingrild Plesner (cds.): Stat, Kirke og Mrnneskerttigheter [State, Church and Human Rights], Oslo: abstrakt forlag, pp. 128-139. 


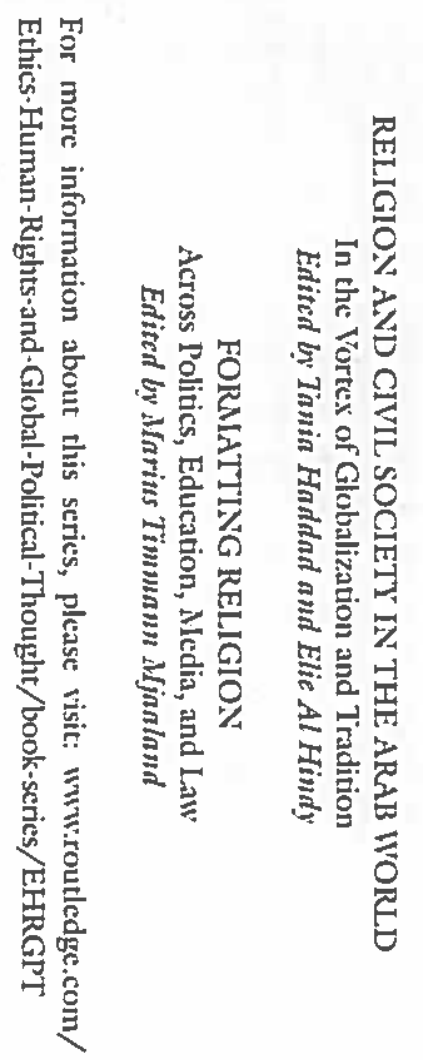

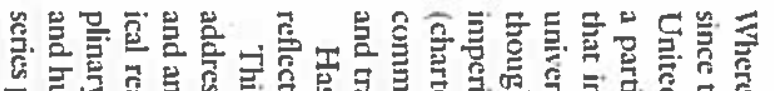

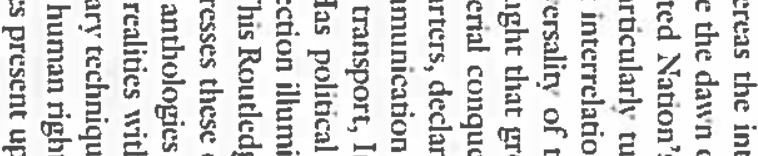

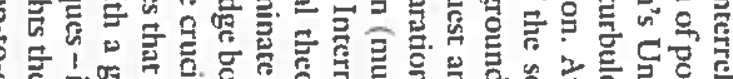

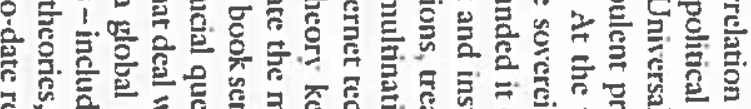

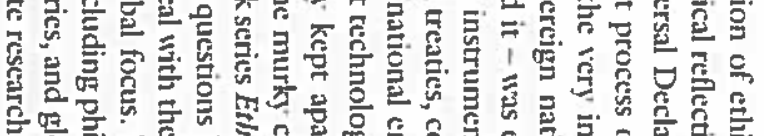

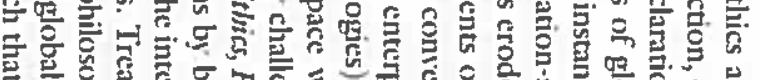

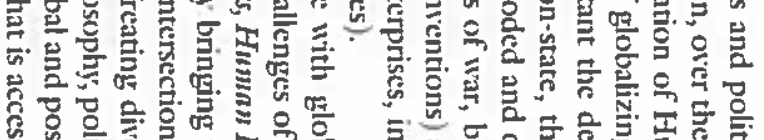

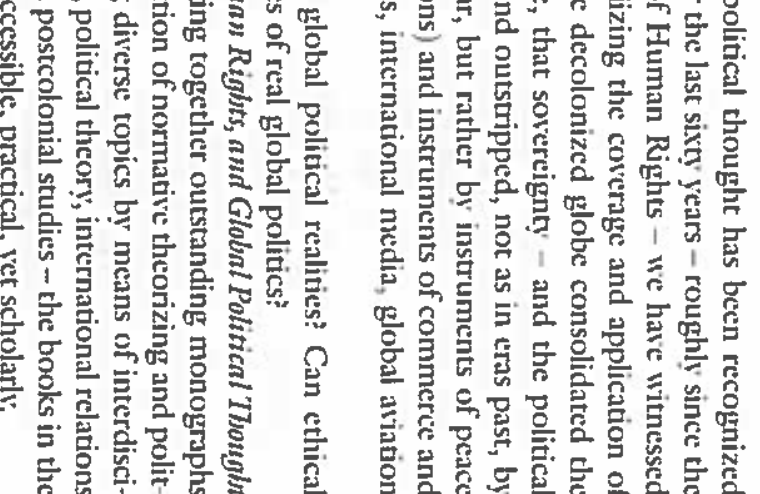
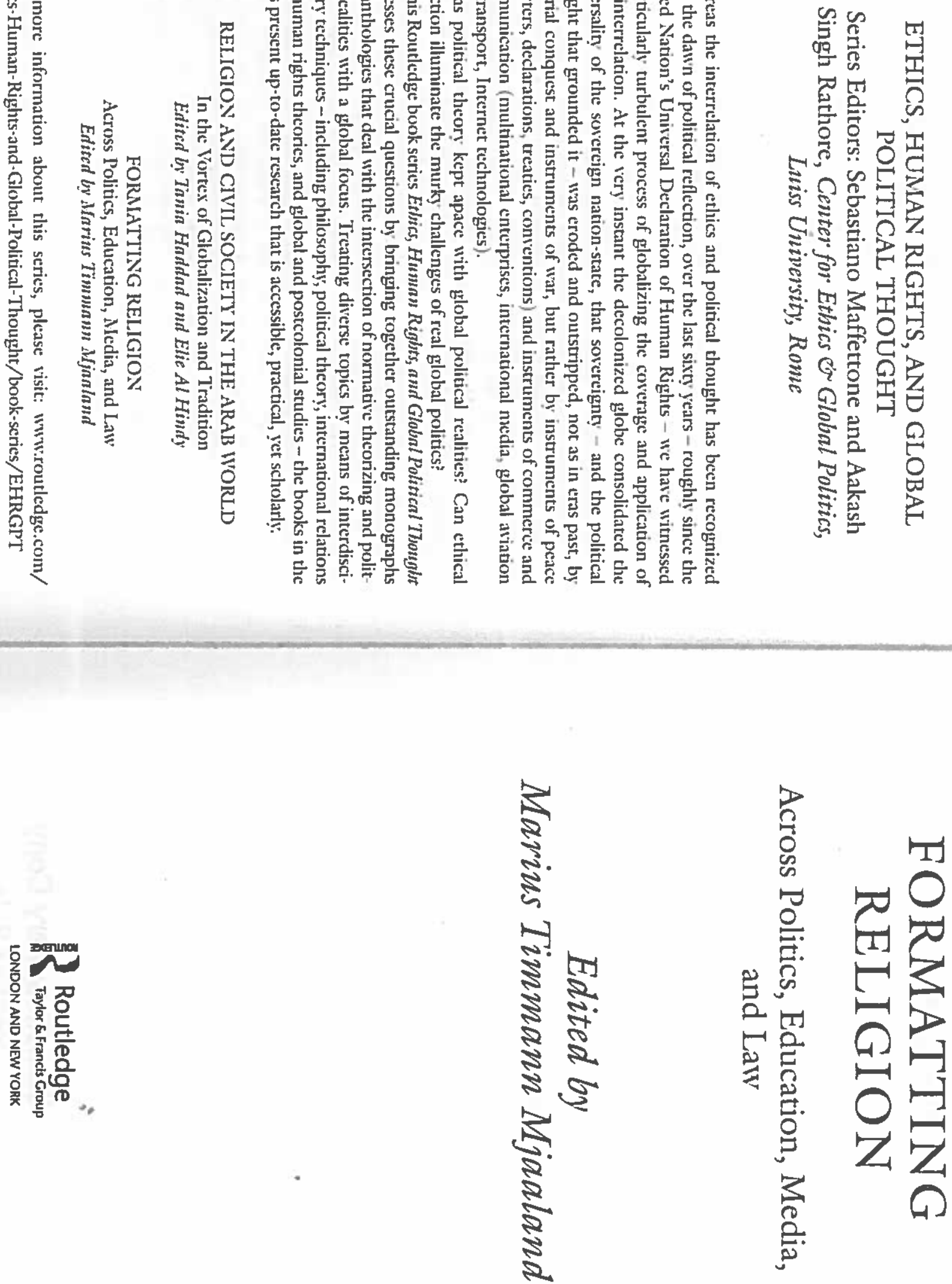


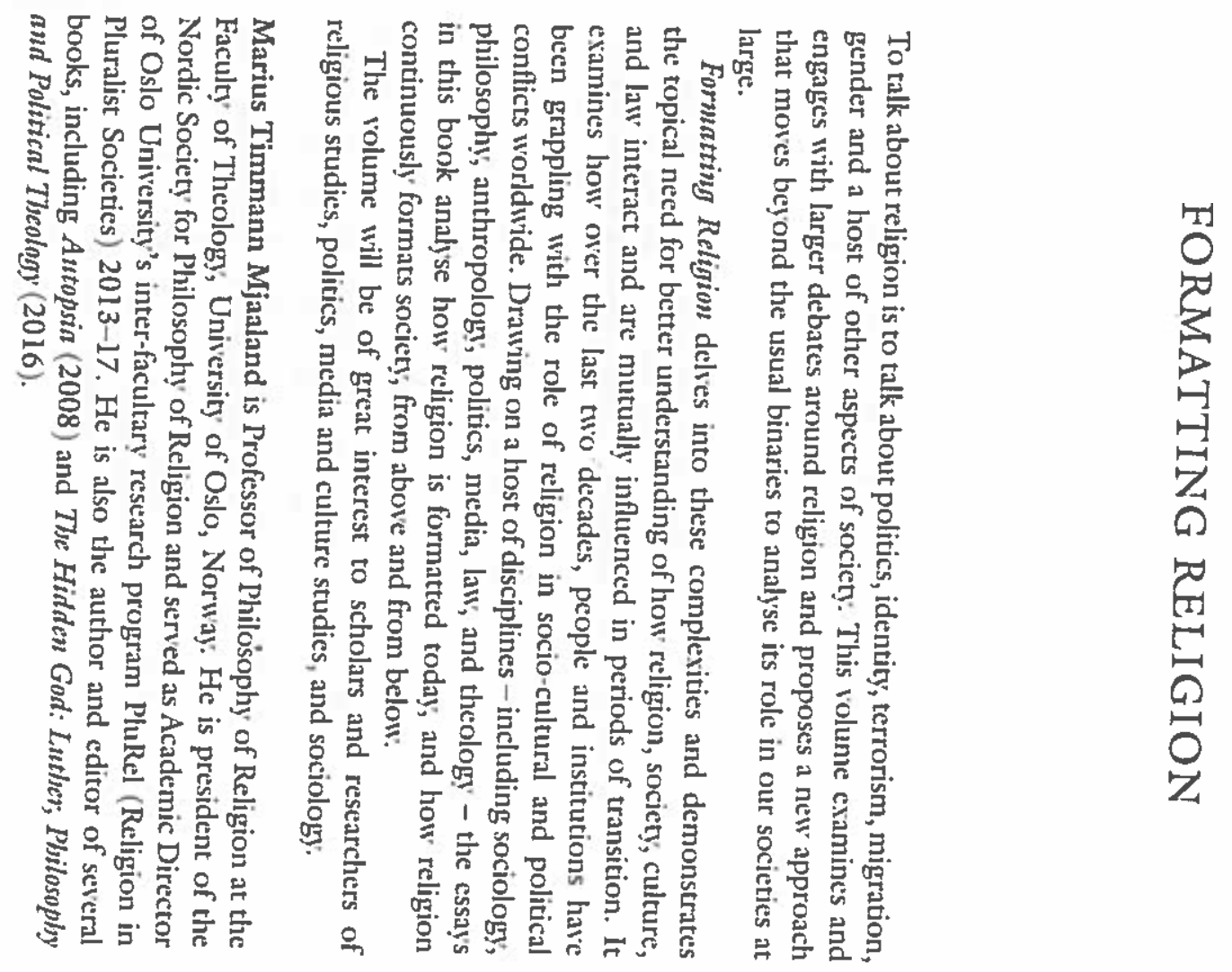



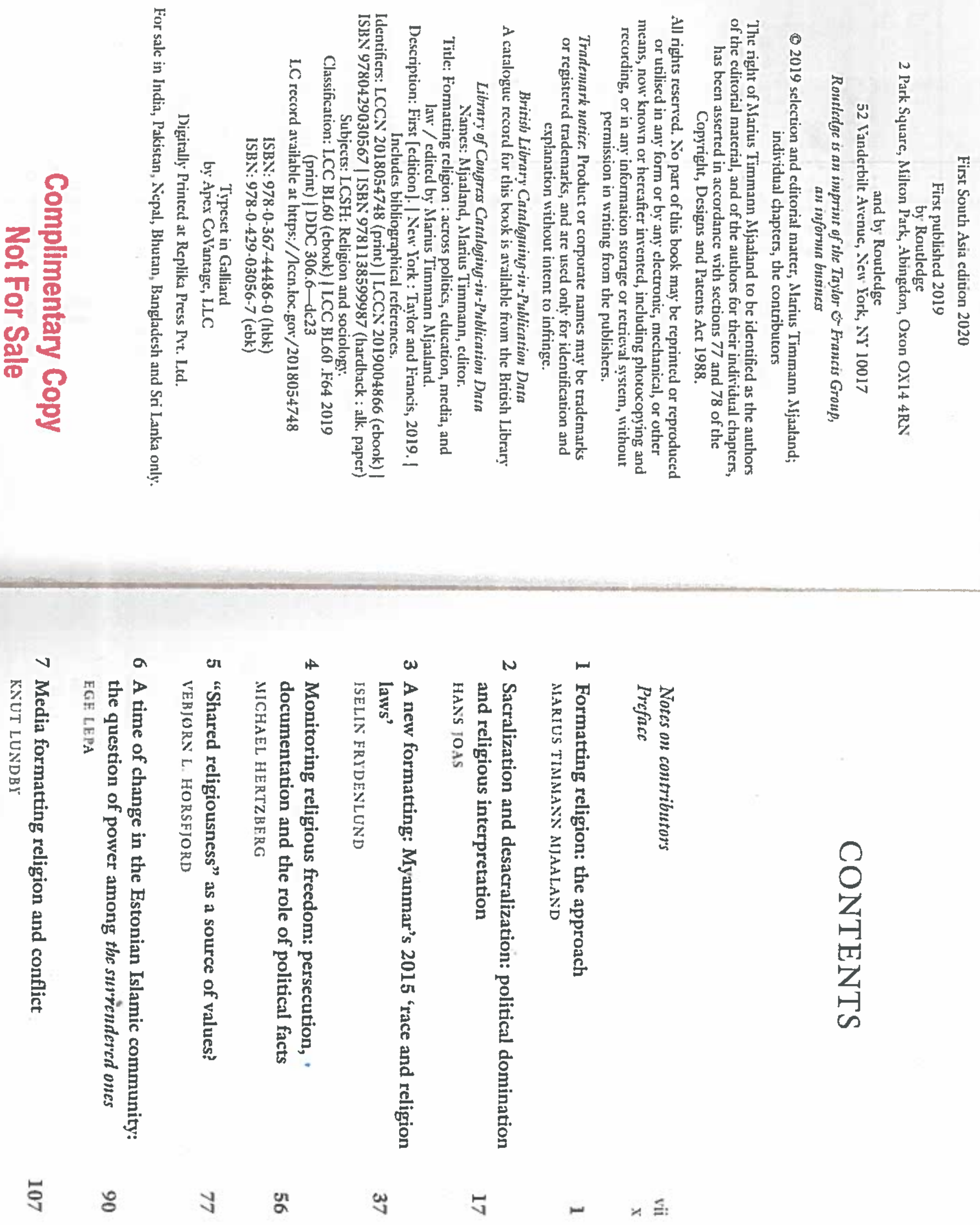


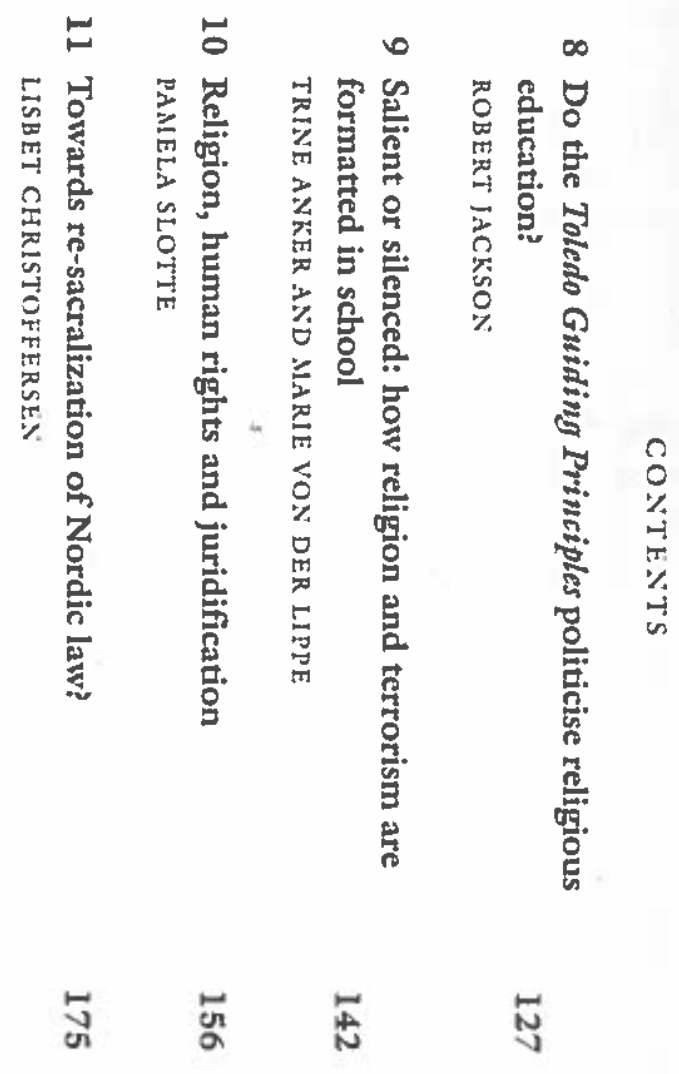

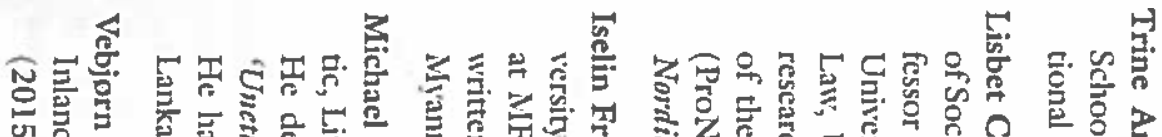

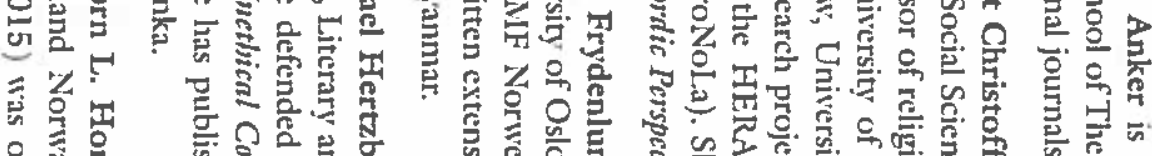

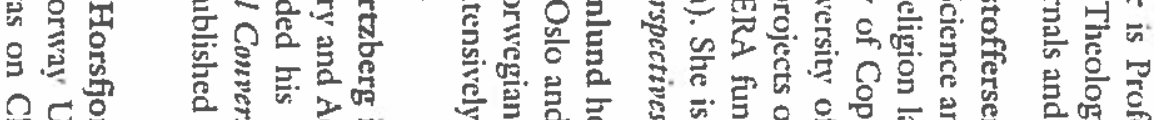
을 空员

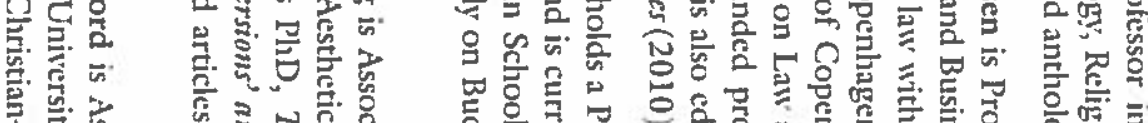

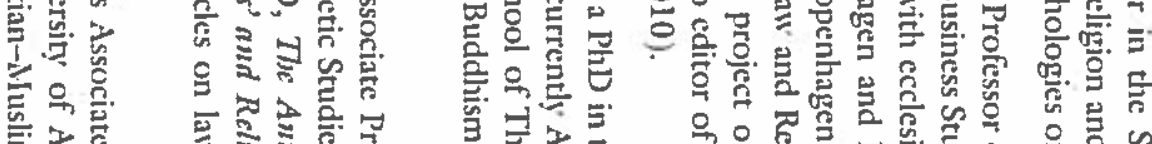

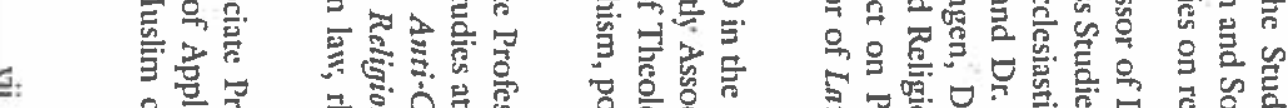

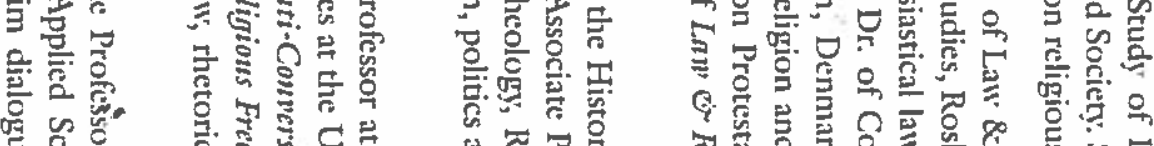

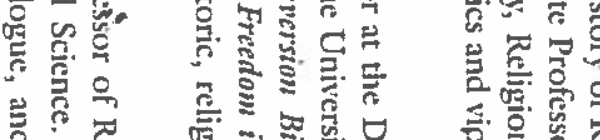

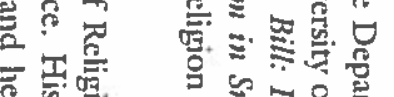

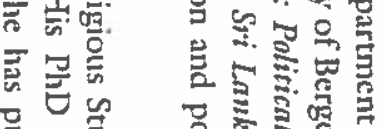

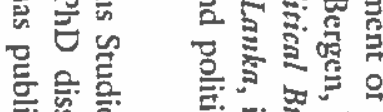

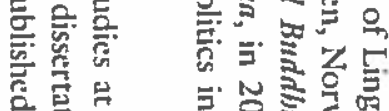

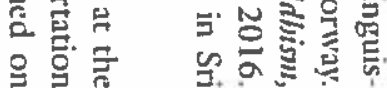

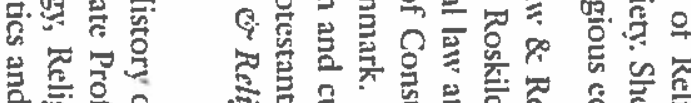

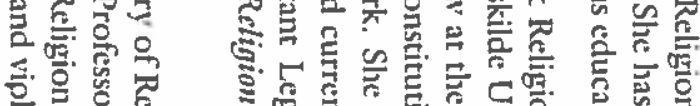

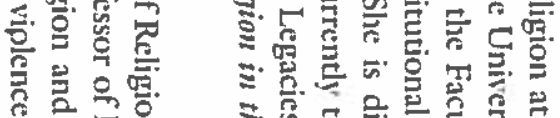

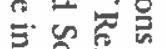

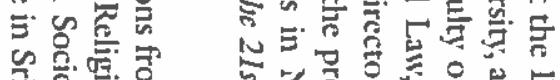

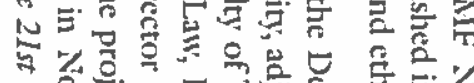

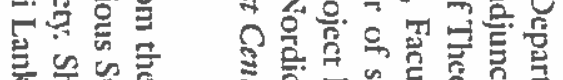
类哭管 言突总

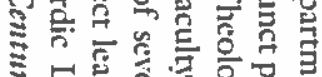

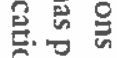
豆另 


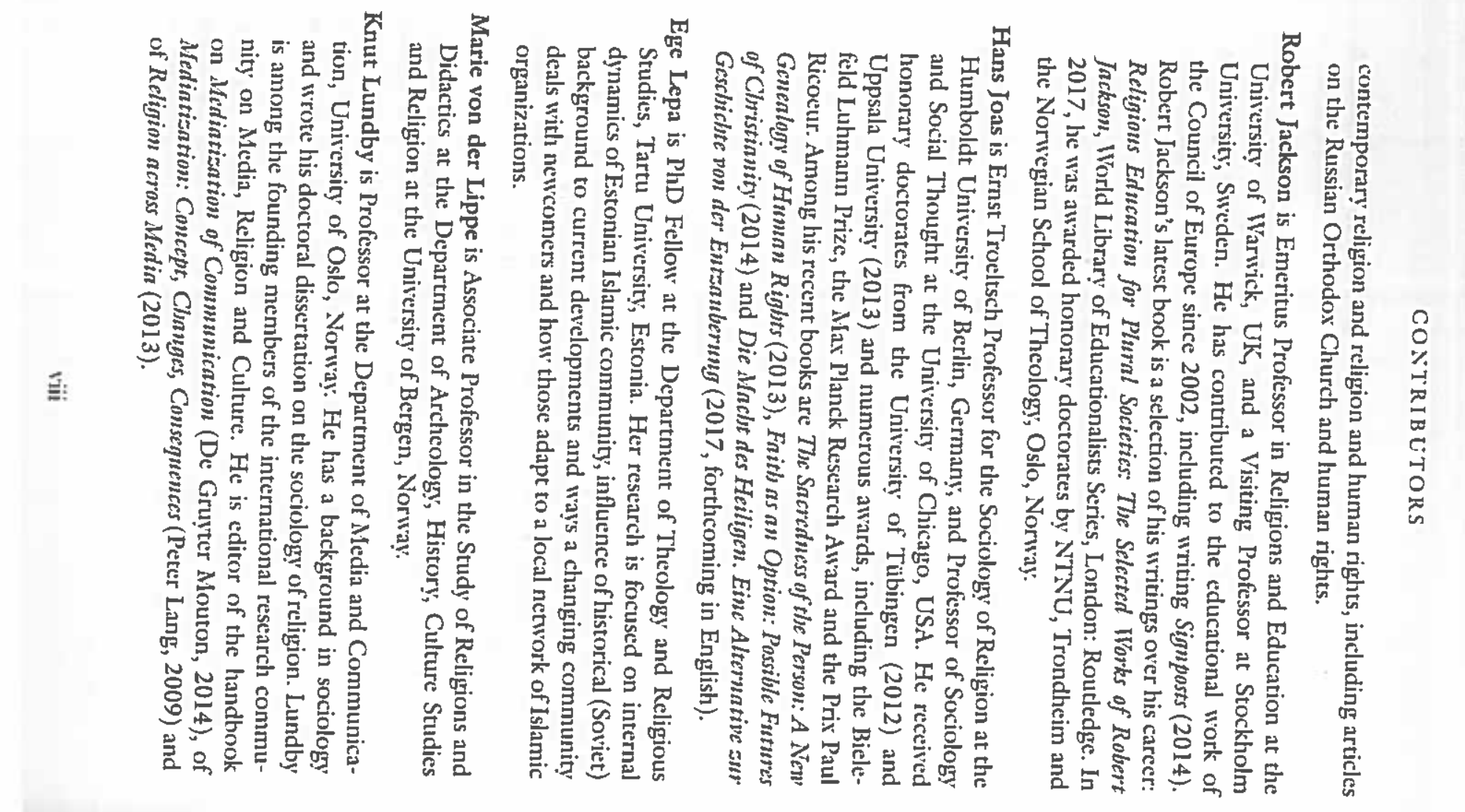




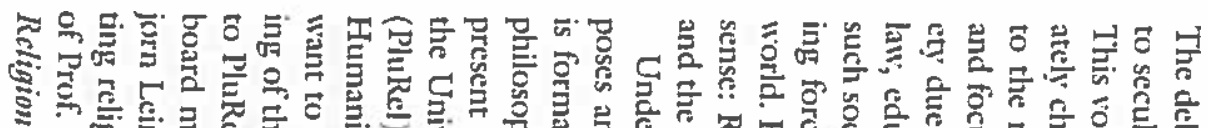

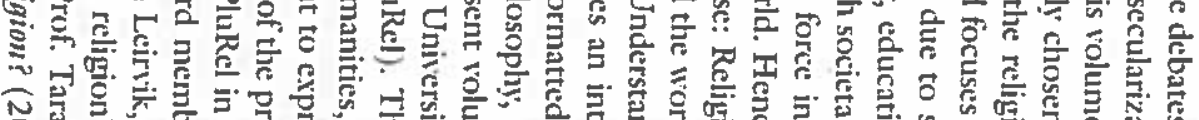

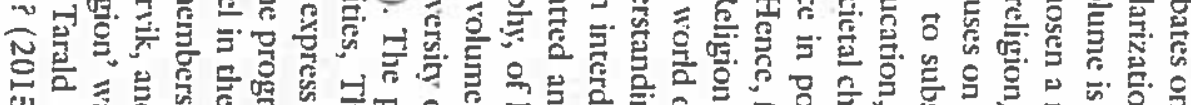

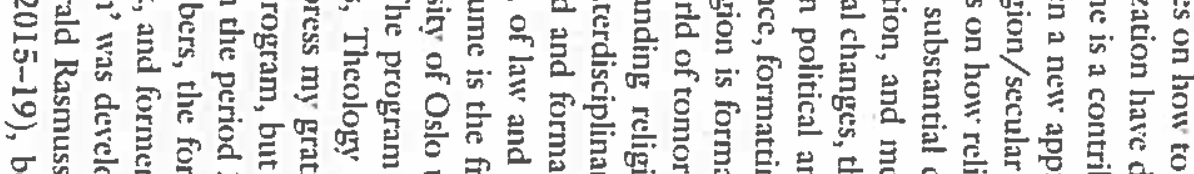

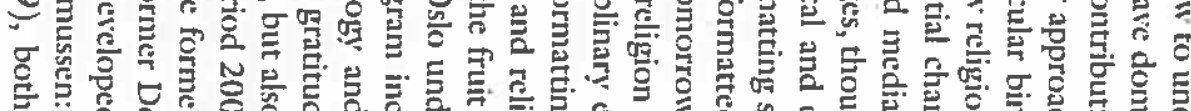

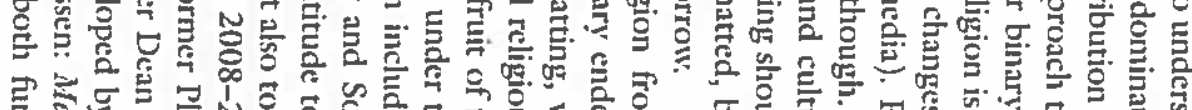

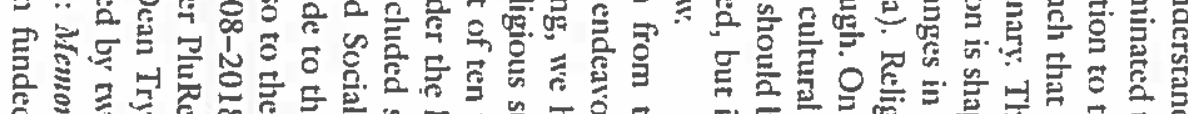

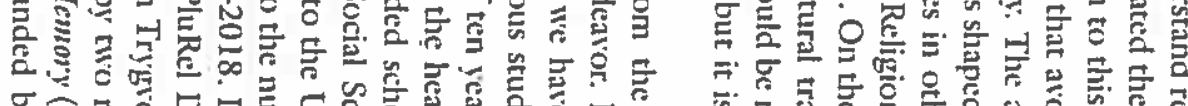

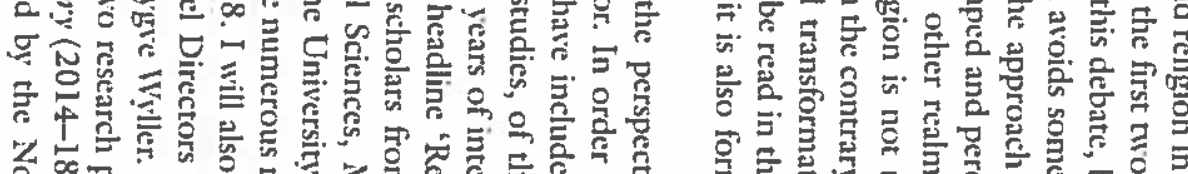

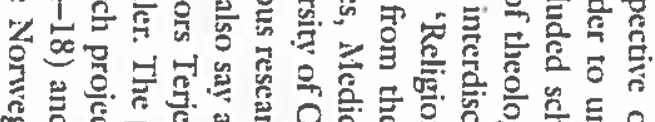

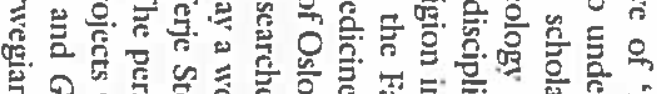

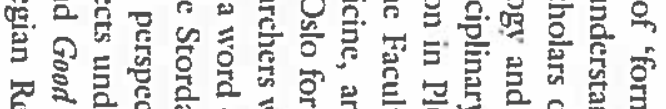

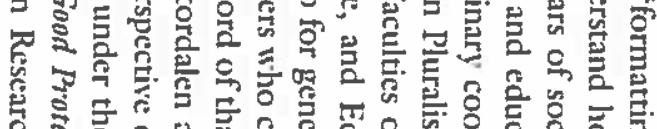

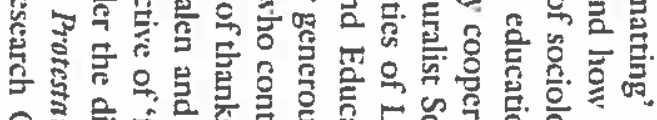

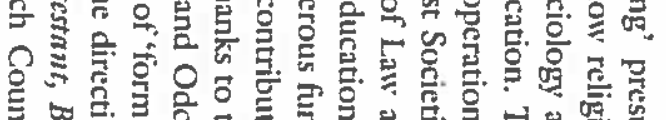

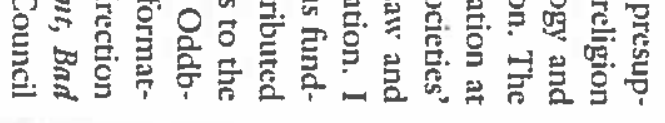

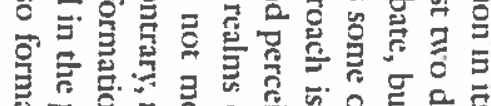

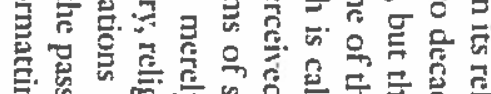

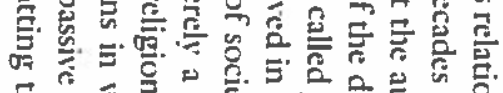
Fo

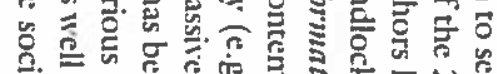

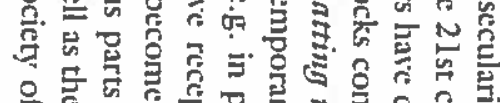
웅

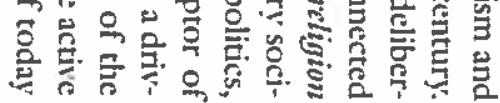

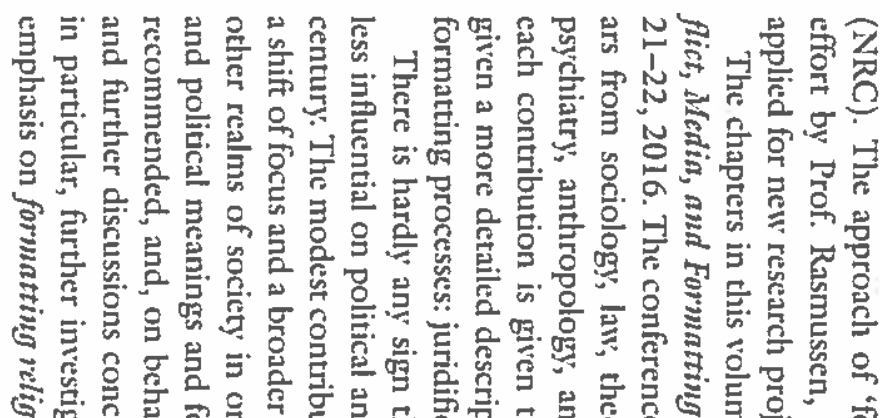

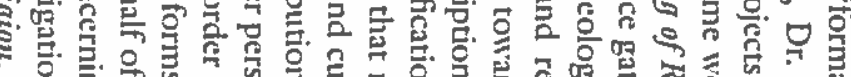

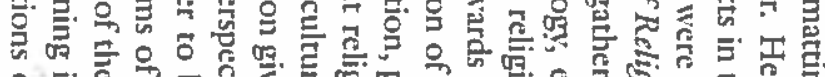

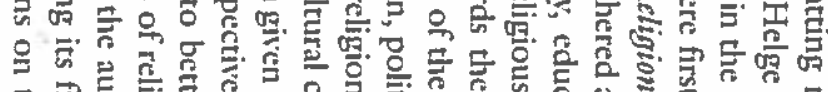

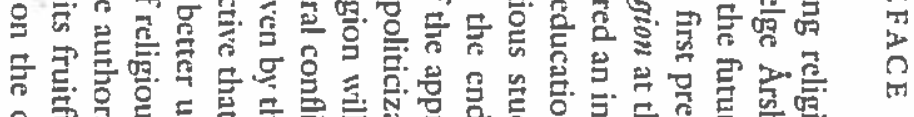

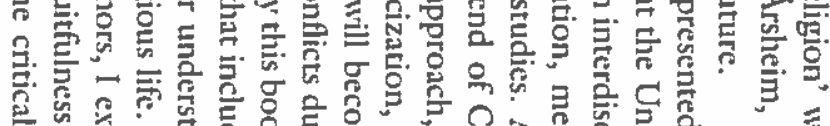

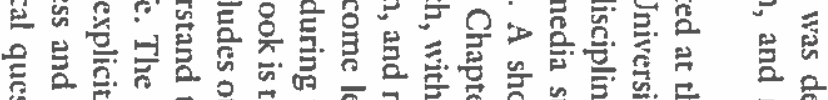

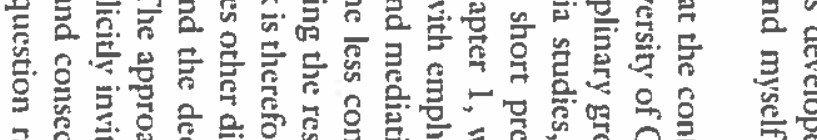

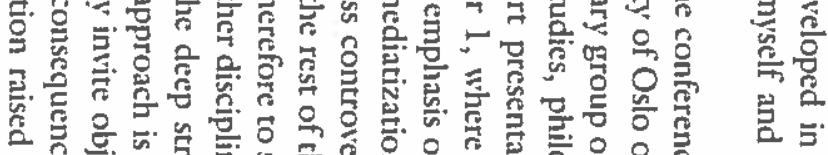

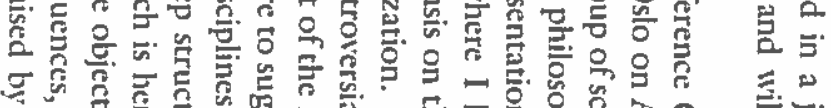

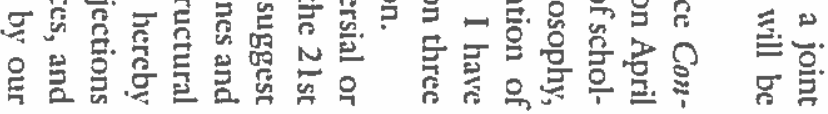

